Article

\title{
Biosorption of Chromium from Textile Wastewater Using Mimosa pudica Tannin Gel
}

\author{
Yanuar Bekti Ramadhan ${ }^{a}$, Aida Nur Sabrina ${ }^{b}$, Endang Kwartiningsih $^{c^{*}}$ \\ Chemical Engineering Department, Faculty of Engineering, Sebelas Maret University, Surakarta, Indonesia \\ Jl. Ir. Sutami No. 36A, Surakarta, Jawa Tengah 57126 \\ E-mail: abekti.y@student.uns.ac.id, baidanur_sabrina@student.uns.ac.id \\ $c^{*}$ end_kwart@staff.uns.ac.id (Corresponding author)
}

\begin{abstract}
The heavy metal content is very dangerous because it can pollute the environment. One of the heavy metals waste commonly found in the textile industry is chromium (Cr). Mimosa pudica is a weed plant and its availability is very abundant. However, it also contains tannin which can be developed into tannin gel biosorbent to adsorption heavy metal content in the wastewater. The purpose of this research is to study Mimosa pudica tannin as a Cr biosorbent from textile wastewater. In this research, the steps to synthesis tannin gel biosorbent are the tannin extraction from the leaves and stems of Mimosa pudica using water solvent and the condensation polymerization using formaldehyde to make it insoluble in water. The yield of Mimosa pudica tannin extract was $9.4 \%$ and the yield of Mimosa pudica tannin gel was $40 \%$. The biosorption process of $\mathrm{Cr}$ from textile wastewater was done using Mimosa pudica tannin gel at the variations of biosorbent mass and contact time. The result showed that the biosorption process at a ratio of biosorbent and solvent $(1: 50 \mathrm{~m} / \mathrm{v})$ and contact time (60 minutes) can reduce the concentration of $\mathrm{Cr}(4 \mathrm{mg} / \mathrm{L})$ to $0.7098 \mathrm{mg} / \mathrm{L}$ that was already below the threshold $(1 \mathrm{mg} / \mathrm{L})$.
\end{abstract}

Keywords: biosorption, condensation polymerization, extraction, Mimosa pudica, tannin gel 


\section{Introduction}

Heavy metals are harmful to the environment. Several heavy metals are carcinogenic and if exposed to agricultural land will endanger life. Heavy metals can be accumulated in a cell of a plant which is animal and human food, also they can be accumulated in a living organism. The effluent of the textile industry can be a contributor to heavy metals [1]. The contamination of heavy metal from the waste textile industry to the environment based on the research has been studied shown in Table 1.

Table 1 The contamination of heavy metal in the environment

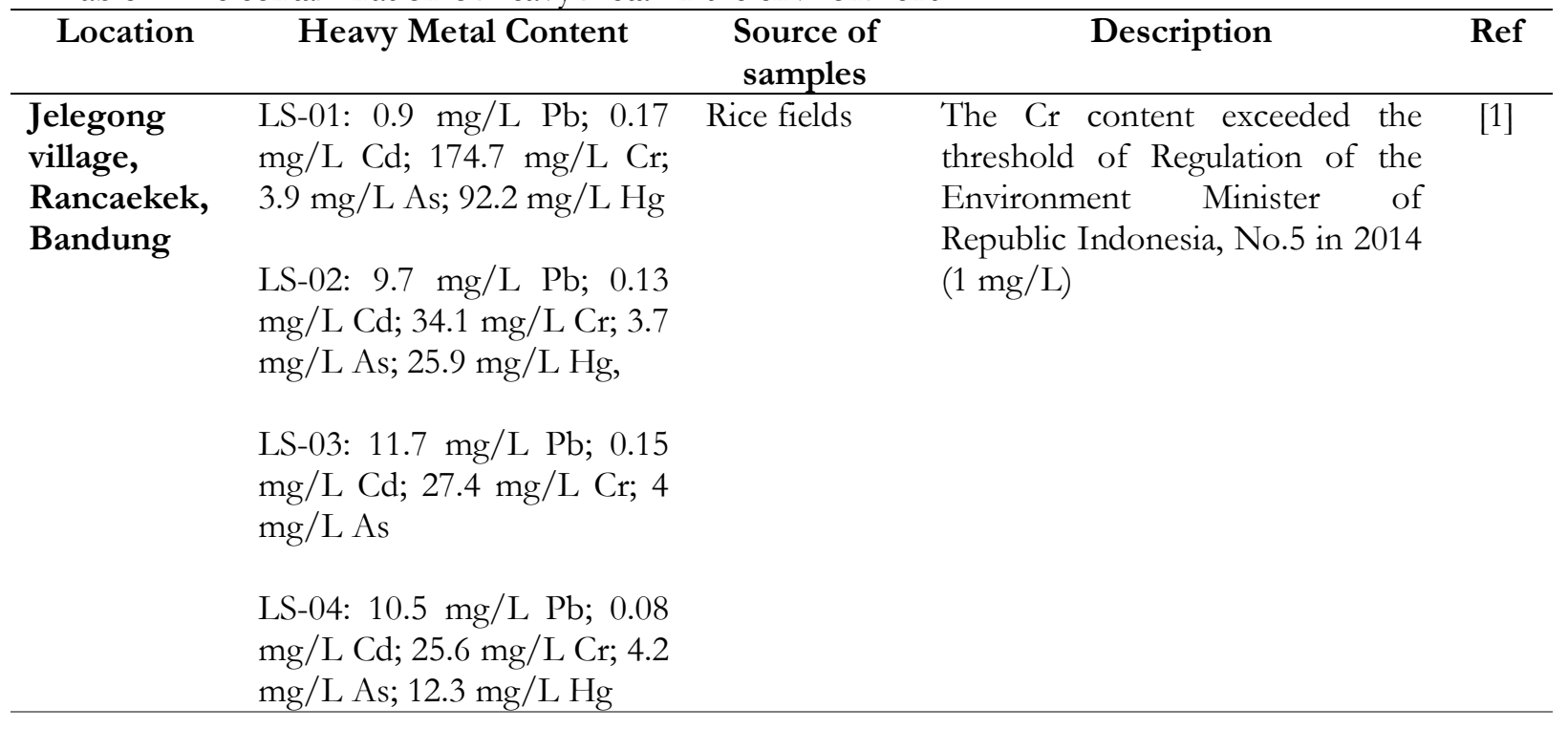

Langsur $\quad 0.0213 \mathrm{mg} / \mathrm{L} \mathrm{Cr} \quad$ Rive
river,
Sidoarjo

The $\mathrm{Cr}$ content was under the threshold of Regulation of the Environment Minister of Republic Indonesia, No.5 in 2014 $(1 \mathrm{mg} / \mathrm{L})$.

$7.05 \mathrm{mg} / \mathrm{kg} \mathrm{Cr} \quad$ Betok fish The $\mathrm{Cr}$ content exceeded the Anabas threshold of Dirjen POM, 1989

testudinaus $(2.5 \mathrm{mg} / \mathrm{kg})$

$\begin{array}{llll}\begin{array}{l}\text { Citarum } \\ \text { river, }\end{array} & \text { point A3 }: 0.075 \mathrm{mg} / \mathrm{LCr} & \text { River } & \begin{array}{l}\text { The } \mathrm{Cr} \text { content exceeded the } \\ \text { Bandung }\end{array} \\ \text { threshold of PP No. } 82 \mathrm{in} 2001 \text { at } \\ \text { water body class II }(0.05 \mathrm{mg} / \mathrm{L})\end{array}$

\begin{tabular}{|c|c|c|c|}
\hline \multirow[t]{3}{*}{$\begin{array}{l}\text { Ranaghat- } \\
\text { Fulia, India }\end{array}$} & $833.5 \mu \mathrm{g} / \mathrm{g} \mathrm{Cr}$ & $\begin{array}{l}\text { Roots of } \\
\text { aquatic weeds }\end{array}$ & \multirow[t]{3}{*}{$\begin{array}{l}\text { The Cr content was highly } \\
\text { contaminated }\end{array}$} \\
\hline & $679.7 \mu \mathrm{g} / \mathrm{g} \mathrm{Cr}$ & $\begin{array}{l}\text { Glossogobius } \\
\text { giuris fish }\end{array}$ & \\
\hline & 79.3-241.6 $\mu \mathrm{g} / \mathrm{g} \mathrm{Cr}$ & $\begin{array}{l}\text { Sediment soil } \\
\text { on October }\end{array}$ & \\
\hline
\end{tabular}

$\begin{array}{ll}\begin{array}{l}\text { Madhabdi, } \\ \text { Bangladesh }\end{array} & 2.15 \mathrm{mg} / \mathrm{L} \mathrm{Cr} \\ & 0.44 \mathrm{mg} / \mathrm{L} \mathrm{Pb}\end{array}$

The Effluent of 34 handloomdyeing industries
The Cr content exceeded IEDS (The Industrial Effluent surface water of Bangladesh i.e. $0.5 \mathrm{mg} / \mathrm{L}$ and IWGV (Irrigation Water Guideline Values) i.e. 0.011 $\mathrm{mg} / \mathrm{L}$ 
In areas of Surakarta, the Cr heavy metal from wastewater was also founded in the Pasar Kliwon textile industry. The $\mathrm{Cr}$ content of its wastewater was $4 \mathrm{mg} / \mathrm{L}$ that exceeds the threshold of the Republic Indonesia government regulation.

Adsorption processes are being widely used by researchers and it has been proved that adsorption is an effective method due to its advantages including stability, utility, low cost, ease of operation, and performance so it should be explored further to recover heavy metal from water. Many low-cost adsorbents have been used to remove heavy metals like industrial effluent (such as fly ash, blast furnace slag and sludge, black liquor lignin, red mud, and waste slurry, etc., agricultural waste (such as rice husk, eggshell, sawdust, rice husk, and lemon peel, microbial such as Bacillus licheniformis and algae such as Cladophora glomerata $[6,7,8]$. Many researchers consider biosorption as an adsorption process that utilizes adsorbents extracted from biological sources [9].

Biosorption has several benefits, including eco-friendly, cheap, high performance, reusable, and the possibility of metal recovery [10]. Biosorbents are commonly low-cost, however, the costs of preparation and pretreatment processes of these materials could not be disregard. Some of the living biomaterials, such as fungi, bacteria, and waste biomass need some cultural media and the implementation of modification procedures which increase the final cost [11]. However, for example on biosorption using brown algae increasing its surface area can reduce the cost of the economy due to increasing effective collisions, making available active sites for heavy metal ions, reducing reaction time, and reducing consumption of biosorbent doses [9].

Biowaste such as agricultural waste was often published in adsorption studies in recent years because of limited porosity, the chemical structure, and surface functional groups related to high adsorption capacity and its capability to adsorb chemically and ion exchange of metal ions from aqueous solutions. Resin tannin is also included in this subclassification of biosorbent [11]. The biosorption process can be done to adsorb $\mathrm{Pb}$ using Persimmon tannin gel with various contact times 10, 20, 30, 40, 50, and 60. The amount $250 \mathrm{~mL} \mathrm{~Pb}$ metal ion with a concentration of $200 \mathrm{mg} / \mathrm{L}$ mixed with 0.1-gram Persimmon tannin gel. The mixture was stirred at $120 \mathrm{rpm}$. Then it was analyzed using Atomic Absorption Spectrophotometer (AAS) to determine the concentration of $\mathrm{Pb}$ metal ions that were adsorbed [12].

Resin tannin can be made from the tannin of various plants e.g. Acacia mangium Wild [13], persimmon [14], mangrove [15] also Mimosa pudica which is a so-called touch-me-not or sensitive plant widely found as a tropical weed in a lot of countries [16]. The availability is very abundant as a weed plant. Mimosa pudica contains tannin which is useful in medical cases such as for bleeding disorders like menorrhagia, dysentery with blood, mucus, and piles [17]. Meanwhile, Mimosa pudica has not been studied as a biosorbent for removing heavy metals in wastewater. The purpose of this research is to study Mimosa pudica tannin as a $\mathrm{Cr}$ biosorbent from textile wastewater. There are two steps to synthesis tannin gel biosorbent. They are the tannin extraction and the condensation polymerization process. Tannin is easily soluble in water so the condensation polymerization process is needed to make it insoluble in water. The extraction of Mimosa pudica tannin was done using water solvent [18]. The condensation polymerization process was done by the reaction of tannin extract and formaldehyde [19].

\section{Materials and Methods}

Materials that were used in this study were the leaves and stems of Mimosa pudica plant, wastewater of the textile industry areas especially the screen printing industry located in Pasar Kliwon, Surakarta, nitric acid $\left(\mathrm{HNO}_{3}\right.$ 65\% Merck, Germany), sodium hydroxide ( $\mathrm{NaOH} 99 \%$ Merck, Germany), formaldehyde $\left(\mathrm{CH}_{2} \mathrm{O} 37,5 \%\right.$, Mallinckrodt chemicals, USA), potassium dichromate $\left(\mathrm{K}_{2} \mathrm{Cr}_{2} \mathrm{O}_{7}\right) 99,9 \%$ Merck, Germany).

\subsection{Extraction of Tannin from Mimosa pudica plant}

Mimosa pudica plant was obtained from the fields and bushes around the Sebelas Maret University, Surakarta. The leaves and stems are washed using clean water, dried in the oven, and crushed using a grinding miller to form a powder. Extraction was carried out by heating Mimosa pudica powder in water as a solvent with a ratio Mimosa pudica powder: water of $1: 20(\mathrm{~m} / \mathrm{v})$ at $100^{\circ} \mathrm{C}$ while stirring for 3 hours [18, $20,21]$. The extract of the extraction process was separated from its residue using filter paper. Then the evaporation process was carried out to remove the water content in the extract of tannin. The drying process was also done in the oven for 24 hours at $100^{\circ} \mathrm{C}$ to get tannin powder. 


\subsection{Synthesis of Mimosa pudica Tannin Gel}

Five grams of tannin powder were dissolved in $32 \mathrm{~mL}$ of $0.125 \mathrm{~mol} / \mathrm{L} \mathrm{NaOH}$ then $30 \mathrm{~mL}$ of distilled water was added and heated at $80^{\circ} \mathrm{C}$. After thoroughly stirring, $2.4 \mathrm{~mL}$ of formaldehyde was added to the mixture and maintained at $80^{\circ} \mathrm{C}$ for 8 hours, this process is called condensation polymerization. Then, it was dried in an oven at $65^{\circ} \mathrm{C}$ for 24 hours. After drying, the tannin gel was crushed into small particles and washed with distilled water and $0.01 \mathrm{~mol} / \mathrm{L} \mathrm{HNO}_{3}$ to remove unreacted $\mathrm{NaOH}$. After that, the washed tannin gel was dried again in the oven so that can be used as an adsorbent [19].

\subsection{Biosorption Process of Cr Using Mimosa pudica Tanin Gel}

Based on the $\mathrm{Cr}$ measurement of wastewater of the textile industry areas especially the screen printing industry located in Pasar Kliwon, Surakarta, one of the wastewater contained a Cr concentration of 4 $\mathrm{mg} / \mathrm{L}$. Biosorption experiments were conducted using Mimosa pudica tannin gel to wastewater that contained $4 \mathrm{mg} / \mathrm{L}$ Cr with a volume of $100 \mathrm{~mL}$ and stirred using a $120 \mathrm{rpm}$ stirrer with variations of mass of biosorbent $(0.5 ; 1 ; 1.5$ and 2 grams or 1:200; $1: 100 ; 1: 67,1: 50 \mathrm{~m} / \mathrm{v})$ and variation of time $(10,20,30$, 40,50 and 60 minutes).

After the adsorption process finished, the filtrate was separated from the residue with Whatman 40 filter paper and analyzed using AAS to measure the final concentration of $\mathrm{Cr}$. The standard solution of $\mathrm{Cr}(\mathrm{VI})(1000 \mathrm{mg} / \mathrm{L})$ was prepared by dissolving potassium dichromate into distilled water. The solution was diluted into various concentrations, i.e. $0,1,2,3$, and $4 \mathrm{mg} / \mathrm{L} \mathrm{Cr}$ for the absorbance measurements using AAS.

\section{Results and Discussion}

\subsection{Extraction Result of Mimosa pudica tannin}

The total mass of extracted tannin obtained was 4.7 grams from the extraction of 50 grams of tannin powder. So, the yield of tannin extracted was $9.4 \%$. The water was used as a solvent because it has high polarity with Synder index 9.0. The more polar the solvent the better it is used for extraction due to its solute [22]. In comparison with other research, the yield of tannin extracted from several plants can be seen in Table 2.

Table 2. The yield of tannin extraction from many plants using water solvent.

\begin{tabular}{ccccc}
\hline Plants & $\begin{array}{c}\text { Extraction } \\
\text { time }\end{array}$ & $\begin{array}{c}\text { The size of the } \\
\text { powder plant }\end{array}$ & Yield & References \\
\hline Allepo pine & $6 \mathrm{~h}$ & $1 \mathrm{~mm}$ & $26 \%$ & {$[23]$} \\
Eucalyptus globulus & $2 \mathrm{~h}$ & - & $14 \%$ & {$[24]$} \\
Areca catechu & $2 \mathrm{~h}$ & $0.250 \mathrm{~mm}$ & $19.5 \%$ & {$[21]$} \\
\hline
\end{tabular}

The yield of tannin extraction from Mimosa pudica in this research was lower $(9.4 \%)$ than other plants. It may be happened to depend on their actual tannin content, time of extraction, and the size of the powder plant [21].

\subsection{Mimosa pudica Tannin Gel}

Tannin gel was made from tannin extract through condensation polymerization reaction with formaldehyde and sodium hydroxide as catalyst. The condensation polymerization reaction is the polymerization of monomer tannin to form a tannin polymer so that it has a stronger molecular structure and is not easily soluble in water. The total mass of tannin gel from this process was 2 grams from 5 grams of Mimosa pudica tannin. So, the yield of Mimosa pudica gel tannin was $40 \%$. 


\subsection{Biosorption Process of Cr Using Mimosa pudica Tannin Gel}

Atomic Absorption Spectrophotometer (AAS) analysis was carried out to determine the heavy metal $\mathrm{Cr}$ that could be adsorbed Mimosa pudica tannin gel. The calibration curve used was made from standard solutions $0,1,2,3$, and $4 \mathrm{mg} / \mathrm{L} \mathrm{Cr}$ which their absorbance was measured using AAS. The absorbance obtained from each standard solution was shown in Figure 1 with linear regression of y (absorbance)= $0.105 \times$ (concentration, $\mathrm{mg} / \mathrm{L}$ ) and a determination coefficient $\left(\mathrm{R}^{2}\right)$ of 0.9538 . The greater $\mathrm{R}^{2}$ value approaching the number 1 indicates the better calibration curve created by the standard solution.

Fig 1. The Standard Calibration Curve

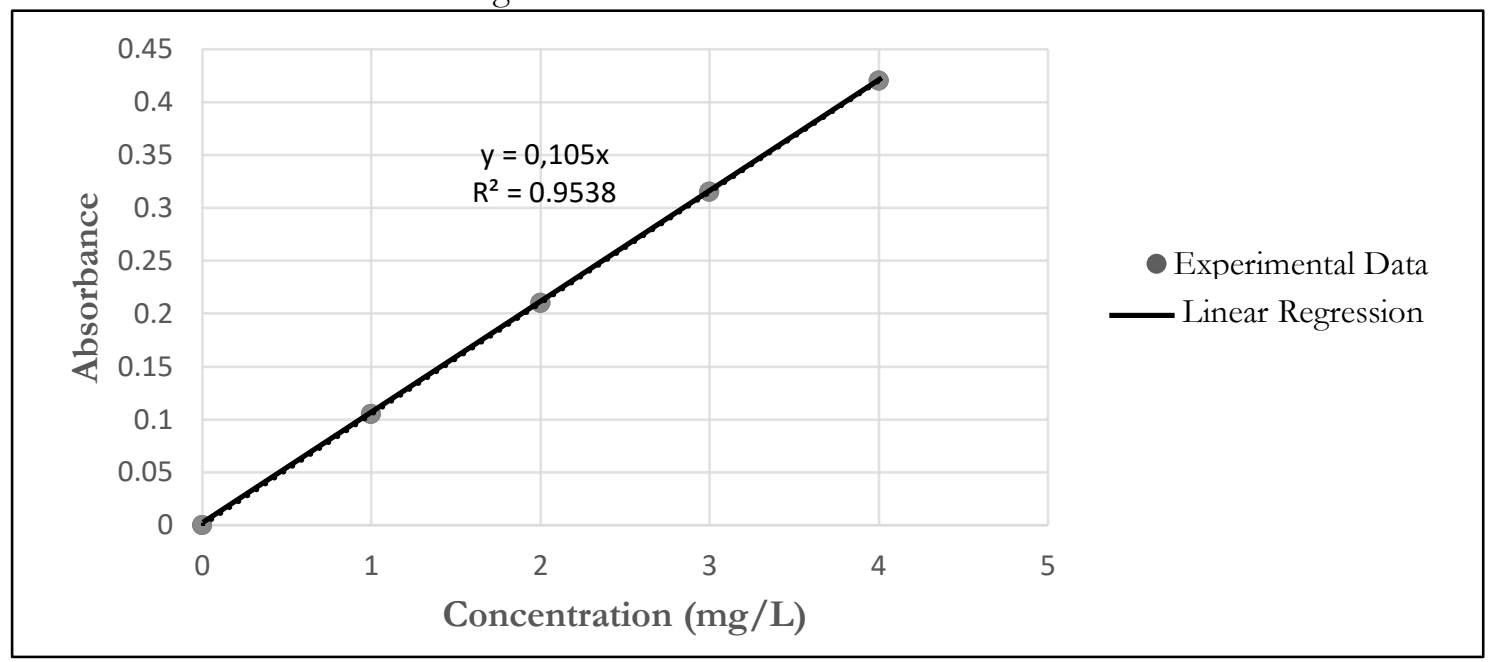

The $\mathrm{Cr}$ concentration of wastewater was $4 \mathrm{mg} / \mathrm{L}$ due to its concentration in one of the textile industry areas in Pasar Kliwon, Surakarta. The results of the analysis of $\mathrm{Cr}$ heavy metal adsorption by Mimosa pudica tannin gel can be seen in Table 3 and Figure 2.

Table 3. Cr Analysis of Biosorption Result Using Mimosa pudica Tannin Gel

\begin{tabular}{|c|c|c|c|c|c|}
\hline \multirow{2}{*}{$\begin{array}{l}\text { Biosorption } \\
\text { Time } \\
\text { (Minutes) }\end{array}$} & \multirow{2}{*}{$\begin{array}{l}\text { Concentration } \\
\text { Cr Before } \\
\text { Biosorption } \\
(\mathrm{mg} / \mathrm{L})\end{array}$} & \multicolumn{4}{|c|}{ Concentration Cr After Biosorption $(\mathrm{mg} / \mathrm{L})$} \\
\hline & & $\begin{array}{c}1: 200 \\
(\mathrm{~m} / \mathrm{v})\end{array}$ & $\begin{array}{c}1: 100 \\
(\mathrm{~m} / \mathrm{v})\end{array}$ & $\begin{array}{c}1: 67 \\
(\mathrm{~m} / \mathrm{v})\end{array}$ & $\begin{array}{c}1: 50 \\
(\mathrm{~m} / \mathrm{v})\end{array}$ \\
\hline 10 & 4 & 3.9386 & 3.4740 & 3.2649 & 2.8115 \\
\hline 20 & 4 & 3.9053 & 3.3304 & 3.0912 & 2.7469 \\
\hline 30 & 4 & 3.8821 & 3.2893 & 2.7568 & 2.2090 \\
\hline 40 & 4 & 3.8752 & 3.2414 & 2.3420 & 1.2583 \\
\hline 50 & 4 & 3.8701 & 3.0840 & 2.0903 & 1.0890 \\
\hline 60 & 4 & 3.8617 & 2.8031 & 1.7627 & 0.7098 \\
\hline
\end{tabular}




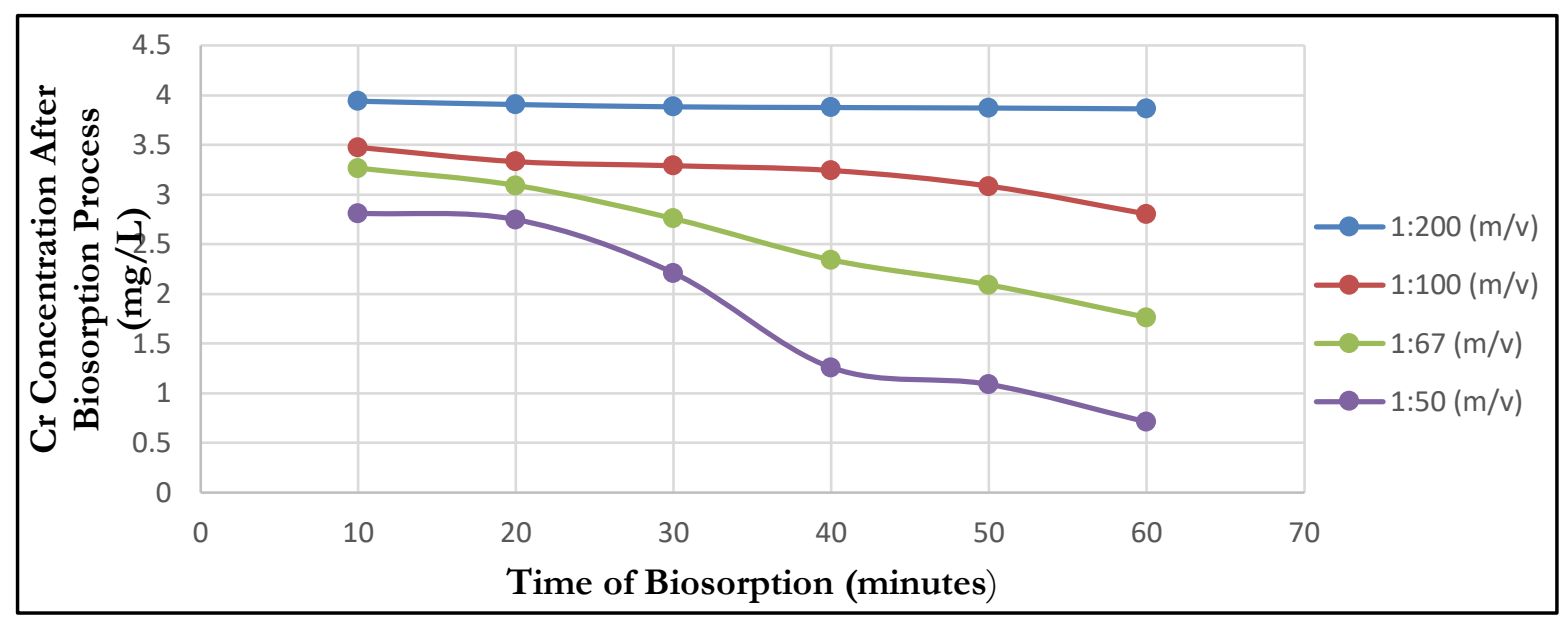

Fig 2. The correlation of Cr Concentration Result and Biosorption Time at Various the Ratio of Tannin Gel Mass and Volume of Solvent

Percent $\mathrm{Cr}$ adsorbed can be determined using equation (1).

$$
\% \text { Cr Adsorbed }=\frac{\mathrm{C}_{0}-\mathrm{C}}{\mathrm{C}_{0}} \times 100 \%
$$

$\mathrm{C}_{0}$ is the initial concentration of $\mathrm{Cr}(\mathrm{mg} / \mathrm{L})$, and $\mathrm{C}$ is the final concentration of $\mathrm{Cr}(\mathrm{mg} / \mathrm{L})$ after the biosorption process. The results of percent $\mathrm{Cr}$ adsorbed can be seen in Table 4 .

Table 4. Percent Cr Adsorbed using Mimosa Pudica Tannin Gel

\begin{tabular}{ccccc}
\hline $\begin{array}{c}\text { Biosorption } \\
\text { Time }\end{array}$ & \multicolumn{4}{c}{ Percent Cr Adsorbed (\%) } \\
\cline { 2 - 5 } (Minutes) & $\mathbf{1 : 2 0 0}$ & $\mathbf{1 : 1 0 0}$ & $\mathbf{1 : 6 7}$ & $\mathbf{1 : 5 0}$ \\
& $(\mathbf{m} / \mathbf{v})$ & $\mathbf{( m / v )}$ & $\mathbf{( m / v )}$ & $\mathbf{( m / v )}$ \\
\hline 10 & 1.54 & 13.15 & 18.38 & 29.71 \\
20 & 2.37 & 16.74 & 22.72 & 31.33 \\
30 & 2.95 & 17.77 & 31.08 & 44.78 \\
40 & 3.12 & 18.97 & 41.45 & 68.54 \\
50 & 3.25 & 22.90 & 47.74 & 72.78 \\
60 & 3.46 & 29.92 & 55.93 & 82.26 \\
\hline
\end{tabular}

The ratio of biosorbent and wastewater volume that was studied in this research were 1:200, 1:100, 1:67, and 1:50 at temperature $30^{\circ} \mathrm{C}$. From Figure 1, Table 1, and Table 2, the highest Cr heavy metal adsorbed at 1:50 (m/v) with percent $\mathrm{Cr}$ adsorbed was $82.26 \%$. It could be concluded that the greater mass of biosorbent, the greater mass of $\mathrm{Cr}$ metal adsorbed. This happened because the active surface of the adsorbent was greater so it could adsorb $\mathrm{Cr}$ heavy metal more. It was appropriate with the research of biosorption that has been studied before as on the table 5

Table 5. Biosorption process using many plant tannin gel

\begin{tabular}{ccccc}
\hline Tannin gel & Heavy metal & $\begin{array}{c}\text { Dose of } \\
\text { Biosorbent }\end{array}$ & The Cr adsorbed & References \\
\hline Accacia mangium & $\mathrm{Pb}$ & $1: 25(\mathrm{~m} / \mathrm{v})$ & $70.81 \%$ & {$[13]$} \\
Persimmon & $\mathrm{Cr}$ & $1: 50(\mathrm{~m} / \mathrm{v})$ & $78 \%$ & {$[14]$} \\
Mangrove & $\mathrm{Pb}$ & $1: 25(\mathrm{~m} / \mathrm{v})$ & $79.94 \%$ & {$[15]$} \\
Mangrove & $\mathrm{Cu}$ & $1: 25(\mathrm{~m} / \mathrm{v})$ & $43.75 \%$ & {$[15]$} \\
\hline
\end{tabular}

The variation of time biosorption process was done at 10, 20, 30, 40, 50, and 60 minutes. From Figure 1, the high biosorption of $\mathrm{Cr}$ heavy metal was at 60 minutes. It can conclude the longer time of biosorption, the greater mass of $\mathrm{Cr}$ was adsorbed. The contact time was appropriate with the research of biosorption $\mathrm{Pb}$ heavy metal from Accacia mangium tannin gel with the result of high biosorption $\mathrm{Pb}$ heavy metal at 60 minutes [13]. The research biosorption of Cr using Persimmon tannin gel had resulted in high biosorption of $\mathrm{Cr}$ heavy metal at 60 minutes [14]. The research of biosorption $\mathrm{Pb}$ and $\mathrm{Cu}$ with Mangrove 
tannin gel that had resulted in high biosorption of $\mathrm{Pb}$ were 60 minutes, and $\mathrm{Cu}$ was 120 minutes [15].

The optimal condition to adsorb Cr from wastewater with Mimosa pudica tannin gel is 1:50 (m/v) at a contact time of 60 minutes with concentrations $\mathrm{Cr}$ in the solution after adsorption was $0,7 \mathrm{mg} / \mathrm{L}$. This concentration was under the threshold of $\mathrm{Cr}$ concentration in textile wastewater based on the regulation of the Environment Minister of Republic Indonesia No.5 in 2014 which was $1 \mathrm{mg} / \mathrm{L}$.

\section{Conclusions}

Based on the results of research that has been done can be concluded as follows:

1. The condensation polymerization process aimed to strengthen the structure of tannin as a biosorbent so the biosorbent was not easily dissolved in water.

2. The yield of Mimosa pudica tannin extract was $9.4 \%$ and the yield of Mimosa pudica tannin gel was $40 \%$.

3. Biosorption of $\mathrm{Cr}$ heavy metal using Mimosa pudica gel tannin can reduce the concentration of $\mathrm{Cr}$ to $0.7098 \mathrm{mg} / \mathrm{L}$ below the threshold of $\mathrm{Cr}$ concentration in textile wastewater based on the regulation the Environment Minister of Republic Indonesia No.5 in 2014 which was $1 \mathrm{mg} / \mathrm{L}$.

4. The optimal condition to adsorb of $\mathrm{Cr}$ heavy metal of wastewater using Mimosa pudica tannin gel was 1:50 $(\mathrm{m} / \mathrm{v})$ with a contact time of 60 minutes.

\section{Acknowledgment}

Thanks to Sebelas Maret University for the financial support through PKM Centre UNS funding in 2020.

\section{References}

[1] Komarawidjaja, W. (2017). Paparan Limbah Cair Industri Mengandung Logam Berat pada Lahan Sawah di Desa Jelegong, Kecamatan Rancaekek, Kabupaten Bandung. Jurnal Teknologi Lingkungan, 18(2), 173. https://doi.org/10.29122/jtl.v18i2.2047

[2] Budiati, S. R., Dewi, N. K., Pribadi, T. A. (2014). Akumulasi Kandungan Logam Berat Chromium (Cr) pada Ikan Betok (Anabas testudienus) yang Terpapar Limbah Cair Tekstil di Sungai Langsur Sukoharjo. Unnes Journal of Life Science. 3(1), 18-23.

[3] Sumantri, A., \& Rahmani, R. Z. (2020). Analisis Pencemaran Kromium (VI) berdasarkan Kadar Chemical Oxygen Demand (COD) pada Hulu Sungai Citarum di Kecamatan Majalaya Kabupaten Bandung Provinsi Jawa Barat 2018. Jurnal Kesehatan Lingkungan Indonesia, 19(2), 144-151. https://doi.org/10.14710/jkli.19.2.144-151

[4] Sanyal, T., Kaviraj, A., \& Saha, S. (2015). Deposition of chromium in the aquatic ecosystem from effluents of handloom textile industries in Ranaghat-Fulia region of West Bengal, India. Journal of Advanced Research, 6(6), 995-1002. https://doi.org/10.1016/j.jare.2014.12.002

[5] Nahar, K., Chowdhury, M. A. K., Chowdhury, M. A. H., Rahman, A., \& Mohiuddin, K. M. (2018). Heavy metals in handloom-dyeing effluents and their biosorption by agricultural byproducts. Environmental Science and Pollution Research, 25(8), 7954-7967. https://doi.org/10.1007/s11356-017-1166-9

[6] Ahmaruzzaman, M. (2011). Industrial wastes as low-cost potential adsorbents for the treatment of wastewater laden with heavy metals. Advances in Colloid and Interface Science, 166(1-2), 36-59. https://doi.org/10.1016/j.cis.2011.04.005

[7] Wen, X., Du, C., Zeng, G., Huang, D., Zhang, J., Yin, L., Tan, S., Huang, L., Chen, H., Yu, G., Hu, X., Lai, C., Xu, P., \& Wan, J. (2018). A novel biosorbent prepared by immobilized Bacillus licheniformis for lead removal from wastewater. Chemosphere, 200, 173-179. https://doi.org/10.1016/j.chemosphere.2018.02.078

[8] Al-Homaidan, A. A., Al-Qahtani, H. S., Al-Ghanayem, A. A., Ameen, F., \& Ibraheem, I. B. M. (2018). Potential use of green algae as a biosorbent for hexavalent chromium removal from aqueous solutions. Saudi Journal of Biological Sciences, 25(8), 1733-1738. https://doi.org/10.1016/j.sjbs.2018.07.011

[9] Beni, A. A., \& Esmaeili, A. (2020). Biosorption, an efficient method for removing heavy metals from industrial effluents: A Review. In Environmental Technology and Innovation (Vol. 17). Elsevier B.V. https://doi.org/10.1016/j.eti.2019.100503

[10] İnce, M., \& Kaplan İnce, O. (2017). An Overview of Adsorption Technique for Heavy Metal Removal 
from Water/Wastewater: A Critical Review. International Journal of Pure and Applied Sciences, 3(2), 10-19. https://doi.org/10.29132/ijpas.372335

[11] Ghomi, A. G., Asasian-Kolur, N., Sharifian, S., \& Golnaraghi, A. (2020). Biosorption for sustainable recovery of precious metals from wastewater. Journal of Environmental Chemical Engineering, 8(4). https://doi.org/10.1016/j.jece.2020.103996

[12] Azis, T., Ahmad, L. O., Rosa, F. E., \& Kadir, L. A. (2019). Study of Equilibrium and Kinetics of Pb(II) in Solution Using Persimmon Tannin Gel as an Adsorbent. Jurnal Kimia Sains Dan Aplikasi, 22(6), 310316. https:// doi.org/10.14710/jksa.22.6.310-316

[13] Nurkaromah, A., \& Sukandar. (2017). Modifikasi Tanin dari Biomassa Daun Akasia (Acacia mangium Wild) Dengan Cara Polimerisasi Sebagai Biosorben Untuk Logam Pb ( II). Journal of Environtment Engineering and Waste Management2(2), 79-91.

[14] Nakajima, A., \& Baba, Y. (2004). Mechanism of hexavalent chromium adsorption by persimmon tannin gel. Water Research, 38(12), 2859-2864. https://doi.org/10.1016/j.watres.2004.04.005

[15] Kartikaningsih, Bachroni, M. A. A., Danarto., Y. C. (2014). Pengambilan Tanin Dari Kulit Kayu Bakau Dan Pemanfaatannya Sebagai Adsorben Logam Berat Cuprum (Cu) Dan Timbal (Pb). Ekuilibium, 13(1), 23-27. https://doi.org/10.20961/ekuilibrium.v13i1.2150

[16] Mapala, K., \& Pattabi, M. (2017). Mimosa pudica Flower Extract Mediated Green Synthesis of Gold Nanoparticles. Nano World Journal, 03(02), 44-50. https://doi.org/10.17756/nwj.2017-045 01(05), 1-6. https://doi.org/10.4236/msce.2013.15001

[17] Varnika, S., Ashish, S., \& Imran, A. (2012). A review on Ethnomedical and Traditional Uses of Mimosa pudica (CHUI-MUI). International Journal Research of Pharmacy 3(2), 41-44.

[18] Mutiar, S., Kasim, A., Emriadi, E., \& Asben, A. (2019). Studi awal tanin dari kulit kayu Acacia auriculiformis A. Cunn. ex Benth. dari hutan tanaman industri untuk bahan penyamak kulit. Majalah Kulit, Karet, Dan Plastik, 34(2), 41. https://doi.org/10.20543/mkkp.v34i2.3967

[19] Sánchez-Martín, J., Beltrán-Heredia, J., \& Gibello-Pérez, P. (2011). Adsorbent biopolymers from tannin extracts for water treatment. Chemical Engineering Journal, 168(3), 1241-1247. https://doi.org/10.1016/j.cej.2011.02.022

[20] Paryanto., Suri, A. K., \& Saputro, R. (2017). Difusi dan Transfer Massa pada Ekstraksi Tanin dari Buah Mangrove ( Rhizophora Stylosa ). Rekayasa Bahan Alam Dan Energi Berkelanjutan, 1(2), 42-48.

[21] Karina, Yuliati, I., \& Sirait, S. M. (2016). Kadar tanin biji pinang ( areca catechu l) berdasarkan lama pemanasan dan ukuran serbuk. Jurnal Hutan Lestari, 4(1), 119-127.

[22] Marnoto, T., Haryono, G., Gustinah, D., \& Putra, F. A. (2012). Ekstraksi Tannin Sebagai Bahan Pewarna Alami Dari Tanaman Putrimalu (Mimosa pudica) Menggunakan Pelarut Organik. Jurnal Reaktor, 14(1), 39-45. https://doi.org/10.14710/reaktor.14.1.39-45

[23] Dababi, I., Gimello, O., Elaloui, E., \& Brosse, N. (2020). Water Extraction of Tannins from Aleppo Pine Bark and Sumac Root for the Production of Green Wood Adhesives. Molecules (Basel, Switzerland), 25(21). https://doi.org/10.3390/molecules25215041

[24] Pinto, P. C. R., Sousa, G., Crispim, F., Silvestre, A. J. D., \& Neto, C. P. (2013). Eucalyptus globulus as Source of Tannin Extract for Application in Leather industry. 2-7. 